\title{
Dogs and the city. The role of urban landscape for dog walking habits, and health benefits for people and dogs
}

Ingrid Sarlöv Herlin

From Animal Obesity - causes, consequences and comparative aspects

Uppsala, Sweden. 14-16 June 2015

\section{Introduction}

The highest proportion of dogs, in Sweden, is found in urbanized counties. Today's sedentary lifestyle leads to worsened health conditions and higher abundance of diabetes and cardiovascular diseases among humans and dogs. While dog ownership leads to an increase in recreational walking is not clear how the urban landscape can contribute to motivation and perceived access.

\section{Objectives}

This study investigates how cities and the urban landscape can be better planned and designed to support dog walking, and through this promote physical and social wellbeing among people and animals.

\section{Methods}

This interdisciplinary study is based on a literature review of relevant fields, such as different approaches to 'walkability' and landscape perception; relations between physical environment and human and animal health; animal human interactions; and planning and management of urban green structure and public spaces.

\section{Results}

Preliminary results show that regular outdoor activities and exercise are positively correlated with people's mental and physical health status, and dog walking has been shown as a viable method for physical activity. The concept of green infrastructure stresses the need for well-connected, easyaccessible, multifunctional green networks. The quality of urban green infrastructure and the experiences they offer

Correspondence: ingrid.sarlov-herlin@slu.se

Department of Landscape Architecture, Planning and Management, Swedish University of Agricultural Sciences, Uppsala, Sweden are important for enhancing recreational use and physical activity.

\section{Conclusions}

Planning, designing and managing and attractive, diverse and well-connected green infrastructure for everyday activities is an important, but neglected task for green space planners and managers that contribute to health and well-being for animals and people.

Published: 25 September 2015

doi:10.1186/1751-0147-57-S1-O20

Cite this article as: Herlin: Dogs and the city. The role of urban landscape for dog walking habits, and health benefits for people and dogs. Acta Veterinaria Scandinavica 2015 57(Suppl 1):O20.
Submit your next manuscript to BioMed Central and take full advantage of:

- Convenient online submission

- Thorough peer review

- No space constraints or color figure charges

- Immediate publication on acceptance

- Inclusion in PubMed, CAS, Scopus and Google Scholar

- Research which is freely available for redistribution

Submit your manuscript at www.biomedcentral.com/submit
() Biomed Central 